\title{
PENGARUH RASIO TINGGI-LEBAR (Hw/Lw) TERHADAP KAPASITAS BEBAN LATERAL, DAN POLA RETAK DINDING GESER BERTULANGAN RINGAN AKIBAT BEBAN SIKLIK
}

\author{
Mochammad Surya Budi Utomo', Ari Wibowo ${ }^{2}$, Achfas Zacoeb ${ }^{3}$ \\ 1,2,3 Jurusan Teknik Sipil, Fakultas Teknik, Universitas Brawijaya \\ J1. MT. Haryono No.167 Malang, 65145, Jawa Timur \\ Email : suryamochammad@gmail.com
}

\begin{abstract}
The shear wall is a vertical structural element of a structural system that serves to withstand lateral loads, whether caused by wind or earthquake. In Indonesia is still often found structural system in old buildings that still use a minimal reinforcement ratio or in this case the lightly shear wall. The lightly sliding wall is believed to have a low lateral load capacity, but in some cases in many countries, the lightweight sliding wall is sufficiently resistant to earthquakes. The height-width ratio is an important aspect in the shear wall structure. Therefore, further research is needed on the effect of high-width ratios. This study discusses the effect of high-width ratios on shear lightly shear walls due to cyclic loads. In this study, the shear wall used as a test specimen with many test specimens was 9 shear wall walls with variations of height-width ratios $(2.0,1.3$, and 1.0) or with sizes: $(800 \times 400 \mathrm{~mm}),(800 \times 600 \mathrm{~mm})$, and $(800 \times 800 \mathrm{~mm})$. The test is carried out by providing cyclic load and axial load constant of $3 \%$ of axial capacity $(\mathrm{Pn})$ of each specimen until the specimen is collapsed by the drift control method. Data in the form of loads and deviations per cycle are recorded for the analysis of collapse mechanisms. While the picture taken as a reference pattern of cracks. The results of the test show that with increasing height-width ratios can produce the smallest lateral load capacity, or vice versa. The lateral load capacity generated by each test object is $S W 2.0$ (1), SW 2.0 (2), SW 2.0 (3), SW 1.3 (1), SW 1.3 (2), SW 1.3 (3), SW 1.0 1), SW 1.0 (2), and SW 1.0 (3) are $1593 \mathrm{~kg}, 1503 \mathrm{~kg}, 1592$ $\mathrm{kg}, 3296 \mathrm{~kg}, 3388 \mathrm{~kg}, 3286 \mathrm{~kg}, 4772 \mathrm{~kg}, 4771 \mathrm{~kg}$, and $4778 \mathrm{~kg}$. Crack patterns that occur on each specimen have the same result that is the same occurrence of opening (gap opening) at the bottom of the wall.
\end{abstract}

Keywords : Shear walls; High-width ratio; Load; Crack

\begin{abstract}
Abstrak
Dinding geser adalah elemen struktural vertikal dari sistem struktural yang berfungsi untuk menahan beban lateral, baik yang disebabkan oleh angin atau gempa bumi. Di Indonesia masih sering dijumpai sistem struktural pada bangunan tua yang masih menggunakan rasio perkuatan minimal atau dalam hal ini dinding geser ringan. Dinding geser ringan diyakini memiliki kapasitas beban lateral yang rendah, tetapi dalam beberapa kasus di banyak negara, dinding geser ringan cukup tahan terhadap gempa bumi. Rasio tinggi-lebar merupakan aspek penting dalam struktur dinding geser. Oleh karena itu, diperlukan penelitian lebih lanjut tentang pengaruh rasio lebar-lebar. Studi ini membahas pengaruh rasio lebar tinggi pada dinding geser ringan akibat beban siklik. Dalam penelitian ini, dinding geser yang digunakan sebagai spesimen uji dengan banyak spesimen uji adalah dinding geser 9 dengan variasi rasio tinggi-lebar $(2,0,1,3$, dan 1,0) atau dengan ukuran: $(800 \times 400 \mathrm{~mm}),(800 \times 600 \mathrm{~mm})$, dan $(800 \times 800 \mathrm{~mm})$. Pengujian dilakukan dengan memberikan beban siklik dan konstanta beban aksial 3\% dari kapasitas aksial (Pn) dari masing-masing spesimen sampai spesimen tersebut runtuh oleh metode kontrol drift. Data dalam bentuk beban dan penyimpangan per siklus dicatat untuk analisis mekanisme keruntuhan. Sedangkan gambar diambil sebagai acuan pola retakan. Hasil pengujian menunjukkan bahwa dengan meningkatkan rasio lebar-tinggi dapat menghasilkan kapasitas beban lateral terkecil, atau sebaliknya. Kapasitas beban lateral yang dihasilkan oleh masing-masing objek uji adalah SW 2.0 (1), SW 2.0 (2), SW 2.0 (3), SW 1.3 (1), SW 1.3 (2), SW 1.3 (3), SW 1.0 1), SW 1.0 (2), dan SW 1.0 (3) adalah $1593 \mathrm{~kg}, 1503 \mathrm{~kg}, 1592 \mathrm{~kg}, 3296 \mathrm{~kg}, 3388 \mathrm{~kg}, 3286 \mathrm{~kg}, 4772 \mathrm{~kg}, 4771 \mathrm{~kg}, 4771 \mathrm{~kg}$, dan 4778 $\mathrm{kg}$. Pola retak yang terjadi pada masing-masing spesimen memiliki hasil yang sama yaitu terjadinya pembukaan yang sama (gap opening) di bagian bawah dinding.
\end{abstract}

Kata kunci: Dinding geser; Rasio lebar tinggi; Beban; Retak 


\section{PENDAHULUAN}

Letak geografis Indonesia menyebabkan sebagian besar wilayahnya berada dalam potensi gempa yang tinggi. Oleh sebab itu, sistem struktur-strukturnya wajib didesain tahan gempa.

Dinding geser merupakan elemen struktur vertikal dari suatu sistem struktur yang berfungsi menahan beban lateral, baik yang diakibatkan angin atau gempa (Park \& Paulay, 1975). Apabila suatu struktur dinding geser mengalami keruntuhan, maka bisa saja mengakibatkan keruntuhan dari keseluruhan sistem struktur gedung. Berdasarkan penelitian (Ottani, 1999; Wibowo.dkk, 2008) menunjukkan bahwa penyebab utama kegagalan dari suatu sistem struktur gedung saat terjadi gempa lebih kepada hilangnya kemampuan menahan beban lateral.

Berdasarkan SNI 03-2847-2013 tentang tata acara persyaratan beton struktural untuk bangunan gedung, bahwa rasio tulangan longitudinal dan transversal minimal untuk dinding geser adalah $0.12 \%$ dan $0.20 \%$. Tetapi pada kenyataannya di Indonesia yang wilayahnya berada dalam intensitas gempa rendah sampai sedang sedikit dijumpai desain dinding geser yang memakai rasio tulangan longitudinal dan transversal minimal atau dinding geser bertulangan ringan. Dinding geser bertulangan ringan umumnya dapat dijumpai di negara-negara yang wilayahnya memiliki intensitas gempa rendah sampai sedang.

Dinding geser bertulangan ringan diyakini memiliki kapasitas beban lateral yang rendah. Berdasarkan hasil penelitian yang dilakukan (Ottani, 1999) yang mana mengklasifikan tingkat kerusakan struktur gedung akibat gempa Mexico city, 1985; Luzon, 1990; Erzincan, 1992; Kobe, 1995 ke dalam 3 level kondisi kerusakan yaitu operational damage, heavy damage, dan collapse (partial or total collapse). Hasil dari penelitian tersebut menunjukkan bahwa, bahkan daerah yang memiliki tingkat intensitas gempa yang tinggi, tingkat kerusakan struktur gedungya relatif rendah dan prosentase kegagalan (collapse) dari struktur gedung tidak lebih dari $5 \%$.

Penggunaan dinding geser bertulangan ringan di Indonesia masih belum banyak dijumpai. Sedangkan dinding geser bertulangan ringan diyakini memiliki kapasitas beban lateral yang rendah. Oleh karena itu, penelitian tentang perilaku dinding geser bertulangan ringan dengan variasi rasio tinggi-lebar akibat beban siklik sangat perlu dilakukan.

Untuk menganalisis besarnya beban lateral dan drift yang terjadi pada tahapan keruntuhan dinding geser, dapat dihitung menggunakan cara yang diusulkan (Wibowo.dkk, 2013) yang terdiri dari beban retak, beban leleh, dan beban ultimit.

1. Beban retak

$$
\begin{gathered}
F_{c r}=\frac{M_{c r}}{H_{w}} \ldots \\
\gamma_{c r}=\frac{M_{c r} H_{w}}{3 E_{c} I_{g}}
\end{gathered}
$$

2. Beban leleh

$$
\begin{gathered}
F_{y}=\frac{M_{y}}{H_{w}} \ldots \ldots \ldots \ldots \ldots \ldots \ldots \ldots \ldots \ldots \ldots \ldots \ldots \ldots \ldots \ldots \ldots \\
\gamma_{y}=\frac{M_{y} H_{w}}{3 E_{c} I_{\text {eff }}} \ldots \ldots \ldots \ldots \ldots \\
I_{\text {eff }}=\frac{\left[\left(\frac{100}{f_{y}}\right)+\left(\frac{P_{u}}{f^{\prime}{ }_{c} A_{g}}\right)\right] I_{g}}{1,2+c} \\
c=\frac{30\left[\left(\frac{100}{f_{y}}\right)+\left(\frac{P_{u}}{f^{\prime}{ }_{c} A_{g}}\right)\right] I_{g}}{H_{w}^{2} t_{w} l_{w}}
\end{gathered}
$$

3. Beban ultimit

$$
F_{u}=\frac{M_{u}}{H_{w}}
$$

- Drift peak

$$
\begin{aligned}
& \gamma_{p e a k}=\gamma_{y}+\gamma_{p l . p} \\
& \gamma_{p l . p}=\left(\phi_{p e a k}-\phi_{y}\right) L_{p} \\
& \phi_{\text {peak }}=\frac{\varepsilon_{c u}}{k_{u} d}=\frac{0,003}{k_{u} d} \\
& \phi_{y}=\frac{3 \gamma_{y}}{H_{w}}
\end{aligned}
$$

- Drift ultimit

$$
\gamma_{u}=\gamma_{y}+\gamma_{p l . u}
$$




$$
\gamma_{p l . u}=\left(\phi_{u}+\phi_{y}\right) L_{p}
$$

Rasio beban aksial rendah

$$
\begin{gathered}
\phi_{u}=\frac{\varepsilon_{s u}}{\left(1-k_{u}\right) d} \ldots \ldots . . \\
k_{u}=\frac{N+A_{s t} f_{s u}}{0,85 f^{\prime}{ }_{c} \beta d t_{w}} .
\end{gathered}
$$

Rasio beban aksial rendah

$$
\begin{gathered}
\phi_{u}=\frac{\varepsilon_{s u}}{k_{u} d} \ldots \ldots \ldots \\
k_{u}=\frac{N-A_{s c} f_{y}}{0,85 f^{\prime}{ }_{c} \beta d t_{w}}
\end{gathered}
$$

\section{METODE PENELITIAN}

Penelitian mengenai "Pengaruh rasio tinggi-lebar $(\mathrm{Hw} / \mathrm{Lw})$ terhadap kapasitas beban lateral dan pola retak dinding geser bertulangan ringan akibat beban siklik" ini termasuk dalam jenis penelitian eksperimental yang dilakukan di laboratorium. Penelitian ini dimulai dari perencanaan benda uji dinding geser sampai pengujian bahan penyusun benda uji dinding geser berupa beton serta baja tulangan dan pengujian siklik dengan hasil berupa hubungan beban-simpangan. Pola retak didapatkan melalui pembacaan hasil eksperimental melalui hubungan bebansimpangan. Sedangkan pola dan panjang retak didapatkan melalui pengamatan visual melalui foto dokumentasi penelitian.
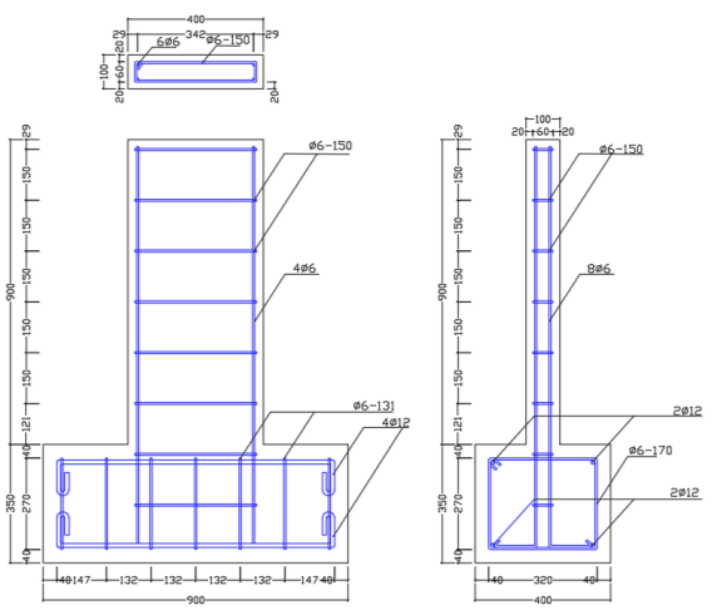

Gambar 1. Benda uji SW 2.0

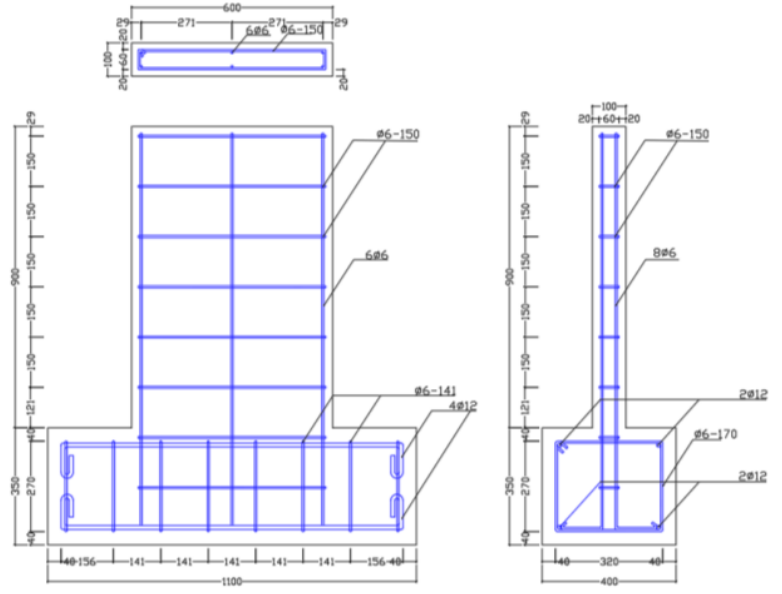

Gambar 2. Benda uji SW 1.3
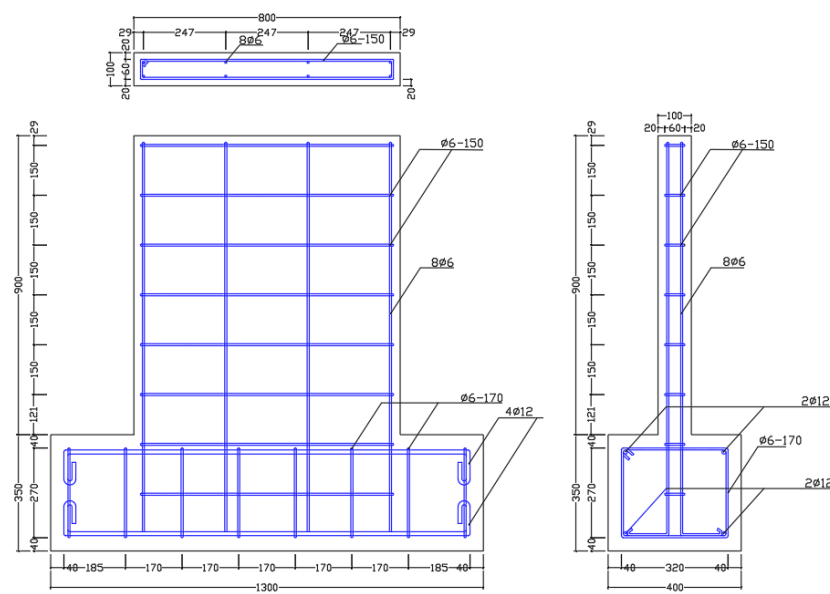

Gambar 3. Benda uji SW 1.0

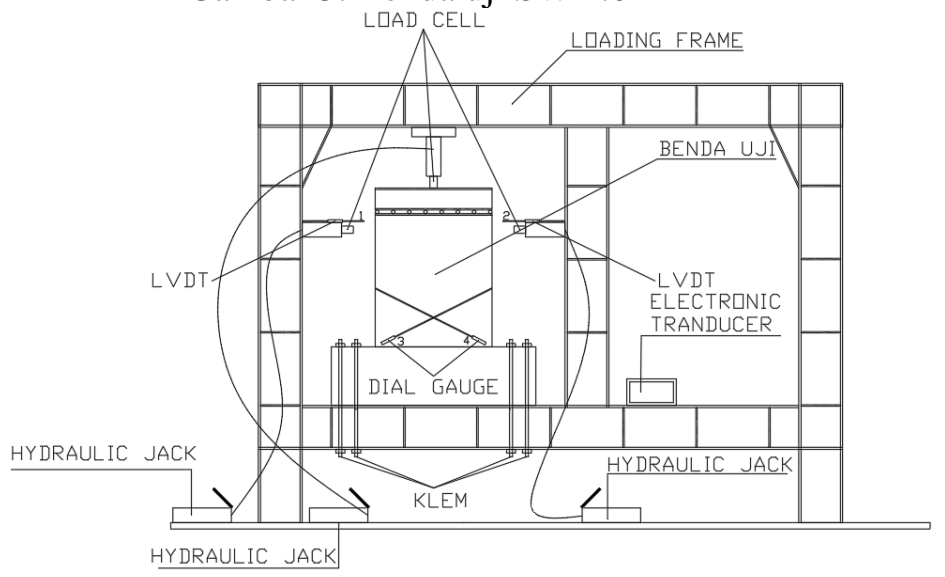

Gambar 4. Setting alat uji

\section{HASIL DAN PEMBAHASAN Properti bahan}

Nilai mutu beton yang digunakan pada benda uji berasal dari hasil uji kuat tekan silinder beton. Jumlah benda uji silinder ukuran $15 \times 30 \mathrm{~cm}$ yang digunakan sejumlah 20 buah. Nilai rata-rata mutu beton $\left(f_{c}{ }^{\prime}\right)$ yang didapat adalah $20.98 \mathrm{MPa}$. Nilai tersebut sudah memenuhi syarat minimum yang 
direncanakan di awal yaitu 20 MPa. Sedangkan jenis diameter tulangan yang dipakai pada benda sebanyak 2 jenis, yaitu $\varnothing 6$ dan Ø12. Dengan total sampel sebanyak 9 buah. Hasil dari pengujian tarik baja tulangan yang dilakukan menunjukkan bahwa tegangan leleh dan ultimit rata-rata dari tulangan yang digunakan pada benda uji adalah 282.94 MPa dan 327.15 MPa untuk tulangan Ø6, 494.91 MPa dan 502.22 $\mathrm{MPa}$ untuk tulangan Ø12. Hasil tersebut juga sudah memenuhi syarat minimum yang direncanakan yaitu $240 \mathrm{MPa}$ untuk tegangan leleh dan $360 \mathrm{MPa}$ untuk tegangan ultimit.

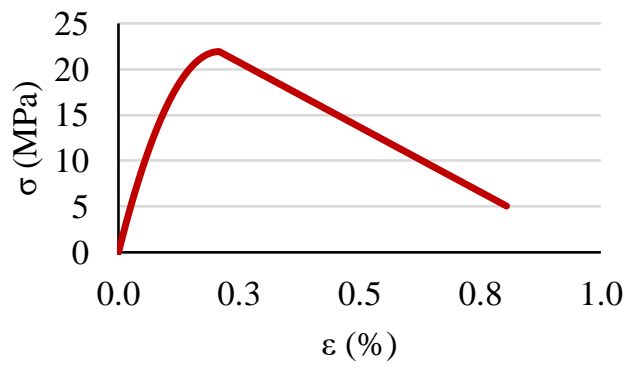

Gambar 5. Diagram tegangan-regangan beton

\section{Kekuatan dinding geser secara teoritis}

Perhitungan kekuatan dinding geser secara teoritis bertujuan untuk mencari nilai beban lateral maksimum, momen maksimum, serta drift maksium yang terjadi pada benda uji dengan pemberian beban aksial 3\% dari

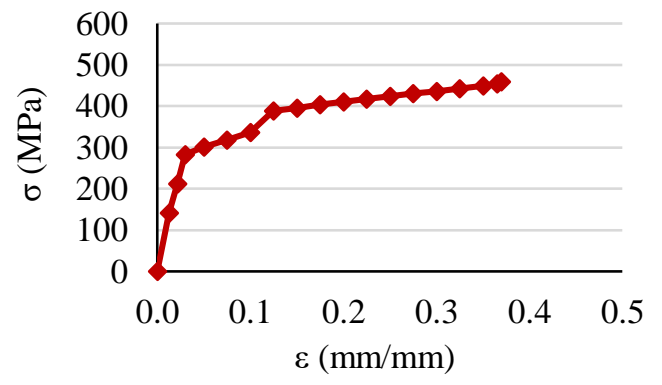

Gambar 6. Diagram tegangan-regangan tulangan $\varnothing 6$

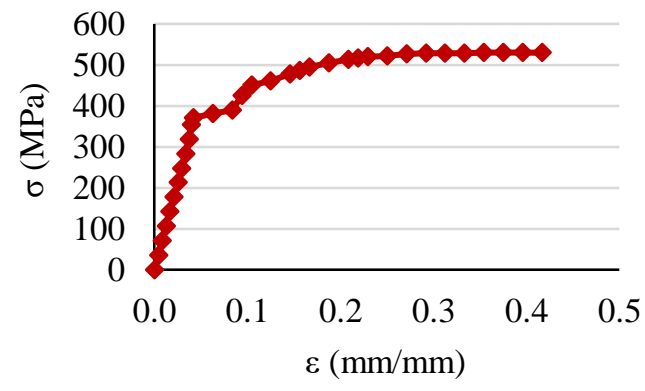

Gambar 7. Diagram tegangan-regangan tulangan $\emptyset 12$

kapasitas aksial nominal masing-masing benda uji. Hasil perhitungan kekuatan dinding geser secara teoritis ditunjukkan Tabel 1.

Tabel 1. Hasil perhitungan dinding geser secara teoritis

\begin{tabular}{|c|c|c|c|c|c|c|c|c|c|c|c|}
\hline & & Satuan & $\begin{array}{c}\text { SW } 2.0 \\
(1)\end{array}$ & $\begin{array}{c}\text { SW } \\
2.0(2) \\
\end{array}$ & $\begin{array}{c}\text { SW } \\
2.0(3) \\
\end{array}$ & $\begin{array}{c}\text { SW } \\
1.3(1) \\
\end{array}$ & $\begin{array}{c}\text { SW } \\
1.3(2) \\
\end{array}$ & $\begin{array}{c}\text { SW } \\
1.3(3) \\
\end{array}$ & $\begin{array}{c}\text { SW } \\
1.0(1) \\
\end{array}$ & $\begin{array}{c}\text { SW } \\
1.0(2) \\
\end{array}$ & $\begin{array}{c}\text { SW } \\
1.0(3) \\
\end{array}$ \\
\hline \multirow{9}{*}{$\begin{array}{c}\text { Perhitungan } \\
\text { Teori }\end{array}$} & Mcr & $\mathrm{kgm}$ & 434 & 434 & 434 & 978 & 978 & 978 & 1742 & 1742 & 1742 \\
\hline & My & $\mathrm{kgm}$ & 1187 & 1187 & 1187 & 1827 & 1827 & 1827 & 2467 & 2467 & 2467 \\
\hline & $\mathrm{Mu}$ & $\mathrm{kgm}$ & 1277 & 1277 & 1277 & 2653 & 2653 & 2653 & 3849 & 3849 & 3849 \\
\hline & Fcr & $\mathrm{kg}$ & 542 & 542 & 542 & 1223 & 1223 & 1223 & 2177 & 2177 & 2177 \\
\hline & Fy & $\mathrm{kg}$ & 1484 & 1484 & 1484 & 2284 & 2284 & 2284 & 3084 & 3084 & 3084 \\
\hline & $\mathrm{Fu}$ & $\mathrm{kg}$ & 1596 & 1596 & 1596 & 3316 & 3316 & 3316 & 4811 & 4811 & 4811 \\
\hline & $\gamma \mathrm{cr}$ & $\%$ drift & 0.071 & 0.071 & 0.071 & 0.190 & 0.190 & 0.190 & 0.28 & 0.28 & 0.28 \\
\hline & $\gamma \mathrm{y}$ & $\%$ drift & 0.210 & 0.210 & 0.210 & 0.670 & 0.670 & 0.670 & 0.88 & 0.88 & 0.88 \\
\hline & $\gamma \mathrm{u}$ & $\%$ drift & 1.400 & 1.400 & 1.400 & 0.740 & 0.740 & 0.740 & 1.14 & 1.14 & 1.14 \\
\hline
\end{tabular}

\section{Mekanisme retak dinding geser}

Perilaku keruntuhan pada dinding geser yang akan dibahas adalah saat retak, saat leleh, dan saat ultimit. Dalam hal ini mekanisme retak dalam ketiga tahapan tersebut akan dibahas berdasarkan perhitungan teoritis dan hasil pengamatan visual.

\section{Benda uji SW 2.0}


Benda uji SW 2.0 yang memiliki rasio tulangan longitudinal $(0.283 \%)$ dan diberi beban aksial sebesar $1424.62 \mathrm{~kg}(n=0.716)$ saat beban lateral masil nol, dan LVDT, dial gauge, strain gauge siap untuk melakukan pengukuran. Berikutnya untuk benda uji SW 2.0 pada pengujian ini dilakukan pembacaan dengan cara kontrol drift (drift control), yang mana drift pertama adalah sebesar $0.25 \%$ sampai benda uji mencapai drift $1.00 \%$, setelah itu dilakukan kenaikan drift sebesar $0.50 \%$ sampai benda uji mengalami kegagalan.

- Saat retak

Ketika drift mencapai $0.125 \%$ atau dalam hal ini beban mencapai $499 \mathrm{~kg}, 699 \mathrm{~kg}$, dan $477 \mathrm{~kg}$, yang mana terbentuk retak horisontal pertama pada bagian dasar dinding geser. Hasil tersebut menunjukkan bahwa perhitungan secara teoritis untuk menghitung kekuatan saat retak $\left(F_{c r}\right)$ adalah $M_{c r} / H_{w}=542 \mathrm{~kg}$ sudah mendekati.

- Saat leleh

Setelah siklus drift mencapai drift leleh yaitu $0.25 \%$, retak semakin bertambah pada bagian dasar dinding geser dan mulai terjadi retak lentur pada bagian tepi-tepi dinding geser. Beban lateral yang tercapai pada saat drift leleh adalah 1356 $\mathrm{kg}, 1398 \mathrm{~kg}$, dan $1386 \mathrm{~kg}$ dengan momen leleh $\left(M_{y}\right) 1085 \mathrm{kgm}, 1118 \mathrm{kgm}$, dan 1109 kgm. Hasil tersebut memperlihatkan perilaku yang mendekati dengan perhitungan secara teoritis $\left(F_{y}\right)$ adalah $M_{y} / H_{w}=1484 \mathrm{~kg}$.

\section{- Saat ultimit}

Saat beban puncak tercapai atau dalam hal ini drift ultimate yaitu saat drift $1.50 \%$, retak dibagian dasar dinding semakin melebar hingga mencapai bagian tepi yang lain dari dinding geser. Selain itu, timbulnya bukaan (gap opening) pada bagian dasar dinding geser, atau istilah lain untuk mengartikan fenomena ini adalah penetrasi leleh (yield penetration) karena lekatan antara beton dibagian bawah dinding geser dengan pondasi bagian atas sudah mencapai tegangan tarik beton $\left(f_{t}\right)$ sekaligus juga regangan ultimate $\left(\varepsilon_{u}\right)$ terjadi pada tulangan . Selain itu, terjadinya tekuk lokal tulangan pada bagian yang mengalami bukaan (gap opening). Beban lateral puncak yang terjadi adalah $1593 \mathrm{~kg}, 1484 \mathrm{~kg}$, dan 1592 $\mathrm{kg}$ dengan momen ultimate $\left(M_{u}\right) 1274.4$ kgm, 1187 kgm, dan 1274 kgm. Hasil tersebut memperlihatkan perilaku yang mendekati dengan perhitungan secara teoritis $\left(F_{u}\right)$ adalah $M_{u} / H_{w}=1596 \mathrm{~kg}$.
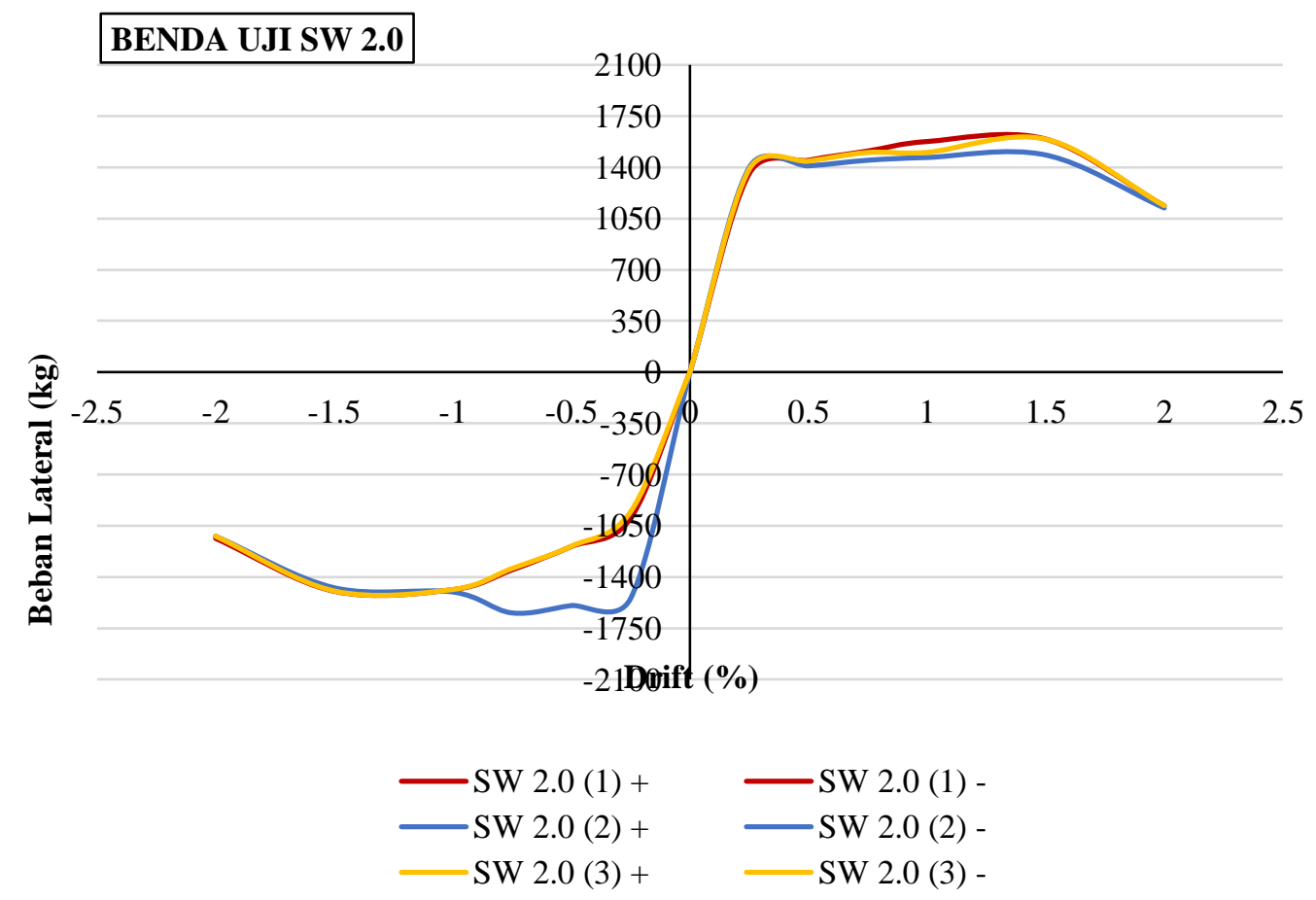

Gambar 8. Kurva beban lateral-drift benda uji SW 2.0 

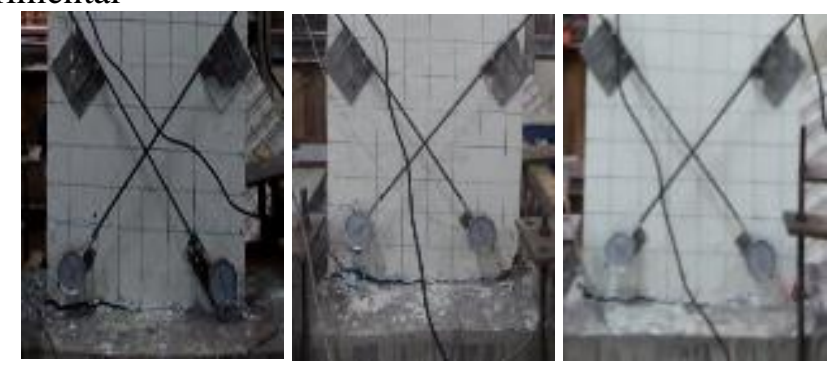

Gambar 9. Pola kerusakan benda uji SW 2.0 (1), (2), dan (3)

Berdasarkan Gambar 9 terlihat jelas bahwa pola retak yang dihasilkan dari benda uji SW 2.0 didominasi dengan dengan retak lentur dibagian tepi-tepi benda uji.Tidak hanya itu saja, timbul bukaan (gap opening) yang cukup besar pada bagian dasar dinding geser dan pondasi bagian atas, itu terjadi karena benda uji SW 2.0 memiliki pola perilaku lentur dominan, sehingga fenomena tersebut dapat terjadi. Selain hal tersebut, pemberian rasio tulangan longitudinal yang kecil dapat juga menghasilkan fenomena tersebut. Dengan adanya bukaan yang cukup besar pada bagian bawah dinding, praktis terjadi perpanjang lokal pada tulangan yang mengalami bukaan. Agar fenomena tersebut bisa diminimalkan, maka pemberian beban aksial bisa ditingkat lagi bisa saja mencapai $5 \%$ dari beban aksial nominal dinding geser.

\section{Benda uji SW 1.3}

Benda uji SW 1.3 yang memiliki rasio tulangan longitudinal $(0.283 \%)$ dan diberi beban aksial sebesar $2120 \mathrm{~kg}(n=0.704)$ saat beban lateral masil nol, dan LVDT, dial gauge, strain gauge siap untuk melakukan pengukuran. Berikutnya untuk benda uji SW 1.3 pada pengujian ini dilakukan pembacaan dengan cara kontrol drift (drift control), yang mana kenaikan drift adalah sebesar $0.125 \%$ sampai benda uji mengalami kegagalan.

\section{- Saat retak}

Saat drift mencapai $0.125 \%$ atau dalam hal ini beban mencapai $1680 \mathrm{~kg}, 1681 \mathrm{~kg}$, dan $1682 \mathrm{~kg}$, yang mana terbentuk retak horisontal pertama (kuat tarik beton sudah terlampaui) pada bagian dasar dinding geser. Hasil tersebut menunjukkan bahwa perhitungan secara teoritis untuk menghitung kekuatan saat retak $\left(F_{c r}\right)$ adalah $M_{c r} / H_{w}=1223 \mathrm{~kg}$ sudah hampir mendekati.

- Saat leleh

Setelah siklus drift mencapai drift leleh yaitu $0.25 \%$, retak semakin bertambah pada bagian dasar dinding geser dan mulai terjadi retak lentur dan sedikit timbul retak geser pada bagian tepi-tepi dinding geser. Beban lateral yang tercapai pada saat drift leleh adalah $2298 \mathrm{~kg}, 2270$ $\mathrm{kg}$, dan $2273 \mathrm{~kg}$ dengan momen leleh $\left(M_{y}\right)$ $1838.4 \mathrm{kgm}, 1838 \mathrm{kgm}, 1816 \mathrm{kgm}, 1818$ kgm. Hasil tersebut memperlihatkan perilaku yang mendekati dengan perhitungan secara teoritis $\left(F_{y}\right)$ adalah $M_{y} / H_{w}=2284 \mathrm{~kg}$.

- Saat ultimit

Saat beban puncak tercapai atau dalam hal ini drift ultimate yaitu saat drift $0.75 \%$, retak dibagian dasar dinding semakin melebar hingga mencapai bagian tepi yang lain dari dinding geser. Selain itu, timbulnya bukaan (gap opening) pada bagian dasar dinding geser, atau istilah lain untuk mengartikan fenomena ini adalah penetrasi leleh (yield penetration) karena lekatan antara beton dibagian bawah dinding geser dengan pondasi bagian atas sudah mencapai kuat tarik beton $\left(f_{t}\right)$ sekaligus juga regangan ultimate $\left(\varepsilon_{u}\right)$ terjadi pada tulangan. Selain itu, terjadinya tekuk lokal tulangan pada bagian bawah dinding yang mengalami bukaan. Beban lateral puncak yang terjadi adalah $3316 \mathrm{~kg}, 3298 \mathrm{~kg}$, dan $3286 \mathrm{~kg}$ dengan momen ultimate $\left(M_{u}\right) 2653 \mathrm{kgm}$, $2638 \mathrm{kgm}$, dan $2629 \mathrm{kgm}$. Hasil tersebut memperlihatkan perilaku yang mendekati dengan perhitungan secara teoritis $\left(F_{u}\right)$ adalah $M_{u} / H_{w}=3316 \mathrm{~kg}$. 


\section{BENDA UJI SW 1.3}

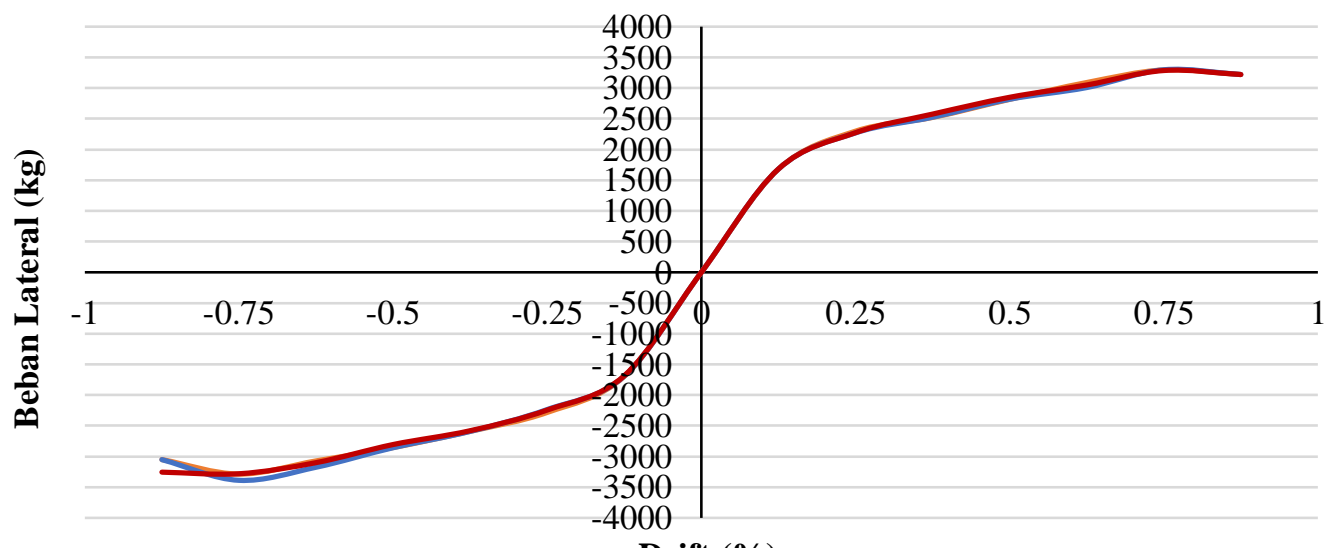

Drift (\%)

$\begin{array}{ll}\text { SW } 1.3(1)+ & \text { SW } 1.3(1)- \\ \text { SW } 1.3(2)+ & \text { SW } 1.3(2)- \\ \text { SW } 1.3(3)+ & - \text { SW } 1.3(3)-\end{array}$

Gambar 10. Kurva beban lateral-drift benda uji SW 1.3

- Pengamatan eksperimental
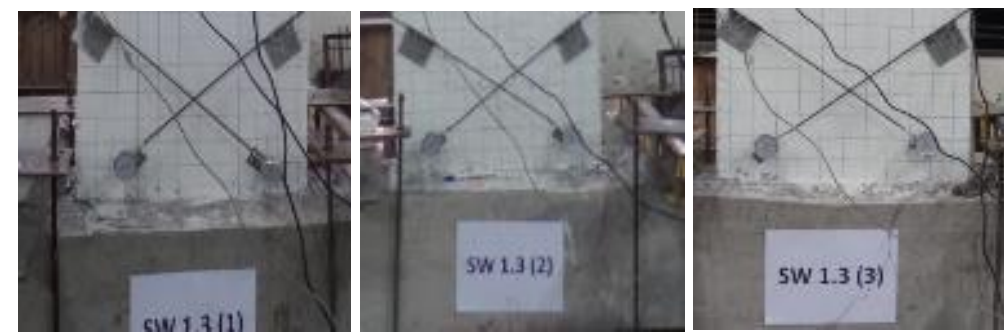

Gambar 11. Pola kerusakan benda uji SW 1.3 (1), (2), dan (3)

Pola retak dari keseluruhan benda uji SW 1.3 adalah mengalami sedikit retak geser dan sebagian dari variasi sedikit mengalami kegagalan pada bagian pondasi. Hal tersebut bisa terjadi, karena pada saat pemberian beban lateral pada salah satu sisi dari dinding

Benda uji SW 1.0 yang memiliki rasio tulangan longitudinal $(0.283 \%)$ dan diberi beban aksial sebesar $2736 \mathrm{~kg}(n=0.698)$ saat beban lateral masil nol, dan LVDT, dial gauge, strain gauge siap untuk melakukan pengukuran. Berikutnya untuk benda uji SW 1.0 pada pengujian ini dilakukan pembacaan dengan cara kontrol drift (drift control), yang mana kenaikan drift pertama adalah sebesar $0.0125 \%$ sampai benda uji mencapai drift $0.125 \%$, setelah itu dilakukan kenaikan drift kedua sebesar $0.025 \%$ sampai mencapai drift $0.375 \%$, setelah itu dilakukan kenaikan drift ketiga sebesar $0.125 \%$ sampai benda uji mengalami kegagalan.

- Saat retak geser, tidak pas pada as dari tebal dan tinggi dinding, sehingga sedikit terjadi adanya pengaruh puntir dan pada akhirnya menghasilkan fenomena tersebut.

\section{Benda uji SW 1.3}

Ketika drift mencapai $0.375 \%$ atau dalam hal ini beban mencapai $2177 \mathrm{~kg}, 2183 \mathrm{~kg}$, $2282 \mathrm{~kg}$ yang mana terbentuk retak horisontal pertama pada bagian dasar dinding geser. Hasil tersebut menunjukkan bahwa perhitungan secara teoritis untuk menghitung kekuatan saat retak $\left(F_{c r}\right)$ adalah $M_{c r} / H_{w}=2177 \mathrm{~kg}$ sudah memperlihatkan perilaku yang mirip. Karena memiliki kapasitas paling besar dalam hal menahan beban lateral dari benda uji yang lain, sehingga sedikit kecil sekali retak terjadi pada tahap ini.

- Saat leleh

Setelah siklus drift mencapai drift leleh yaitu $0.50 \%$, retak semakin bertambah 
pada bagian dasar dinding geser. Beban lateral yang tercapai pada saat drift leleh adalah $2992 \mathrm{~kg}, 2792 \mathrm{~kg}$, dan $2990 \mathrm{~kg}$ dengan momen leleh $\left(M_{y}\right) 2394 \mathrm{kgm}$, $2234 \mathrm{kgm}$, dan $2392 \mathrm{kgm}$. Hasil tersebut memperlihatkan perilaku yang mendekati dengan perhitungan secara teoritis $\left(F_{y}\right)$ adalah $M_{y} / H_{w}=3084 \mathrm{~kg}$.

- Saat ultimit

Saat beban puncak tercapai atau dalam hal ini drift ultimate yaitu saat drift $0.875 \%$, retak terus bertambah dibagian bawah dinding geser tanpa terjadi bukaan (gap opening). Beban lateral puncak yang terjadi adalah $4772 \mathrm{~kg}, 4771 \mathrm{~kg}$, dan 4778 $\mathrm{kg}$ dengan momen ultimate $\left(M_{u}\right) 3818$ kgm, $3817 \mathrm{kgm}$, dan $3822 \mathrm{kgm}$. Hasil tersebut memperlihatkan perilaku yang mendekati dengan perhitungan secara teoritis $\left(F_{u}\right)$ adalah $M_{u} / H_{w}=4811 \mathrm{~kg}$.

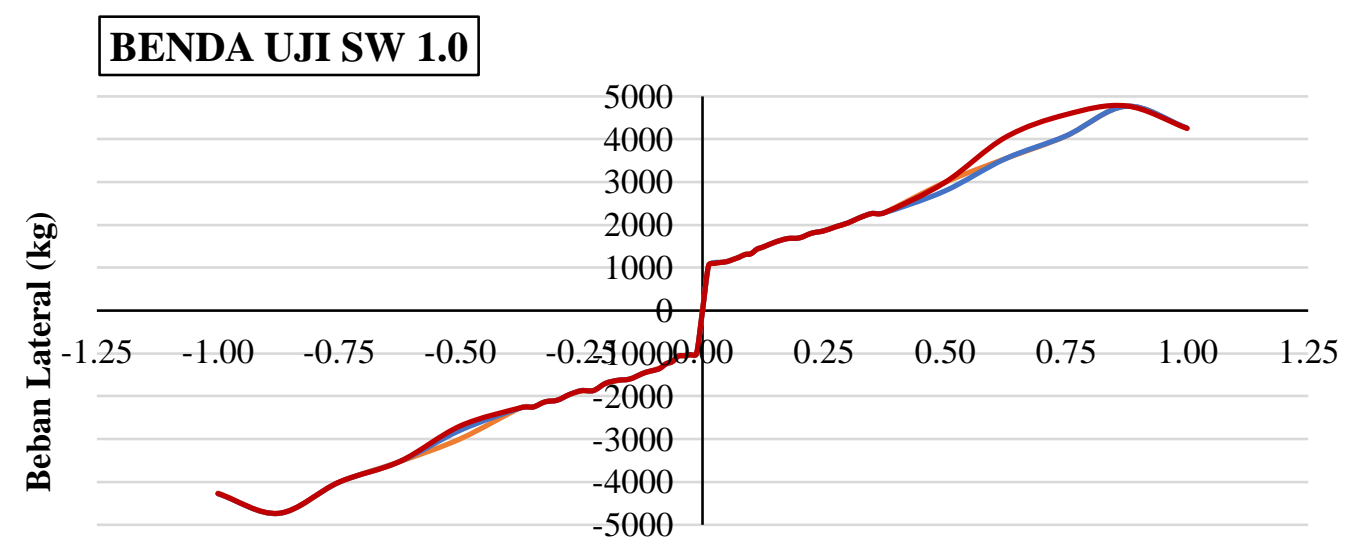

Drift (\%)

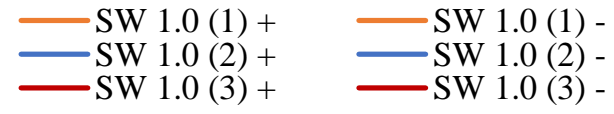

Gambar 12. Kurva beban lateral-drift benda uji SW 1.0

- Pengamatan eksperimental
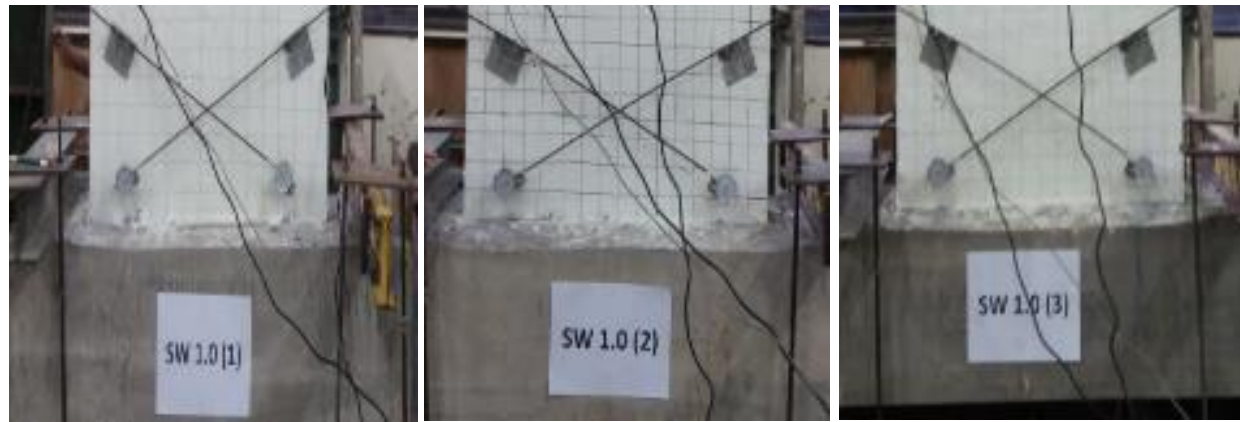

Gambar 13. Pola kerusakan benda uji SW 1.0 (1), (2), dan (3)

Pola retak keseluruhan dari benda uji SW 1.0 adalah retak kecil dibagian bawah dinding geser, hal tersebut bisa terjadi karena benda uji SW 1.0 memiliki tingkat kekakuan paling tinggi, jika dibandingkan dengan benda uji SW 2.0, dan SW 1.3, sehingga retak yang dihasilkan relatif lebih kecil. Selain hal itu, benda uji SW 1.0 yang memiliki aspek rasio $(a)=1.0$ sehingga memiliki pola perilaku geser dominan, dan hal itu yang menyebabkan retak yang dihasilkan sangat kecil atau bahkan tidak ada. 
Selain dipegaruhi hal-hal teknis tersebut, retak ada sebagian benda uji yang hampir tidak terjadi keretakan sama sekali, karena kapasitas loading frame yang tidak memadahi untuk diteruskan pada salah satu variasi benda uji SW 1.0.

\section{KESIMPULAN DAN SARAN}

\section{Kesimpulan}

Berdasarkan hasil penelitian serta hasil perhitungan secara teoritis, dan pembahasan data, dapat ditarik beberapa kesimpulan guna menjawab permasalahan dalam penelitian perilaku dinding geser bertulangan ringan dengan pengaruh aspek rasio (Hw/Lw) akibat beban siklik, yaitu sebagai berikut:

1. Material penyusun benda uji meliputi beton dan baja tulangan sudah memenuhi syarat yang direncanakan diawal, yaitu untuk mutu beton rata-rata $\left(f_{c}\right.$ ') yang didapat adalah $20.98 \mathrm{MPa}$, nilai tersebut sudah memenuhi syarat minimum yang direncanakan yaitu $20 \mathrm{MPa}$, sedangkan untuk baja tulangan juga sudah memenuhi persyaratan yaitu memiliki tegangan leleh $\left(f_{y}\right)$ rata-rata yaitu $282.94 \mathrm{MPa}$, nilai tersebut juga sudah memenuhi syarat minimum yang direncanakan yaitu sebesar $240 \mathrm{MPa}$.

2. Kapasitas beban lateral maksimum yang dapat dihasilkan masing-masing benda uji sangat berbeda. Benda uji SW 1.0 menghasilkan kapasitas beban lateral paling besar dibandingkan dengan benda uji SW 2.0, dan SW 1.3.

3. Pola retak secara keseluruhan dari benda uji sudah sangat baik, yaitu dapat mewakili kajian teori di bab II, dimana pada saat pengujian benda uji SW 2.0 memiliki pola retak lentur dominan ditambah dengan adanya bukaan (gap opening) antara dasar dinding geser dengan pondasi bagian atas, hal itu bisa terjadi karena pengaruh pemberian rasio tulangan longitudinal dan transversal yang minimal pada struktur dinding geser. Benda uji SW 1.3 memiliki perilaku yang mirip dengan benda uji SW 2.0, yaitu terjadi bukaan (gap opening) antara dasar dinding geser dengan pondasi bagian atas, akan tetapi bukaan yang dihasilkan relatif lebih kecil dibandingkan dengan benda uji
SW 2.0. Tidak hanya itu saja, benda uji SW 1.3 juga memiliki pola retak lentur dan sedikit timbul retak geser. Untuk benda uji SW 1.0, sedikit terjadi retak pada dasar dinding, retak itupun tidak banyak terjadi di seluruh bagian bawah dinding geser. Itu terjadi karena benda uji SW 1.0 memiliki kekakuan sangat tinggi, sehingga retak yang dihasilkanpun sedikit.

\section{Saran}

Dari penelitian yang telah dilakukan mengenai perilaku dinding geser bertulangan ringan dengan pengaruh aspek rasio (Hw/Lw) akibat beban lateral siklik, dapat direkomendasikan beberapa hal sebagai berikut :

1. Agar menghasilkan mutu benda uji yang seragam, sebaiknya untuk peneliti selanjutnya melakukan pengecoran untuk sekali pengadukan atau dalam hal ini bisa memakai ready mix.

2. Karena pengujian ini hanya memakai mutu beton normal, sebaiknya dikembangkan untuk memakai mutu beton tinggi.

3. Selain dipengaruhi aspek rasio, rasio tulangan longitudinal dan transversal, dan mutu beton, pemberian beban aksial juga dapat mempengaruhi hasil dari benda uji, sebaiknya untuk peneliti selanjutnya memberikan pengaruh beban aksil kurang dari 3\%, agar dapat menghasilkan daktilitas pada masing-masing benda uji menjadi lebih tinggi.

4. Pada saat pengujian berlangsung, lebih diperhatikan lagi mengenai pemberian beban lateral pada benda uji, atau dalam hal ini posisi load cell harus pas pada as dinding yang akan diberi beban. Hal tersebut dilakukan supaya tidak terjadi guling pada proses pengujian berlangsung.

\section{DAFTAR PUSTAKA}

ASTM E 2126, Standard Test Methods for Cyclic (Reversed) Load Test for Shear Resistance of Walls for Building, ASTM Designation E 2126 - 05,2005.

Badan Standarisasi Nasional. . (2013).SNI 03-2847 Tata Cara Persyaratan Beton Struktural untuk Bangunan Gedung. Jakarta : Badan Standarisasi Nasional. 
Dazio, A., Beyer, K., \& Bachmann, H. (2009). Quasi-Static Cyclic Tests and Plastic Hinge Analysis of RC Structural Walls. Engineering Structures. Vol. 31. pp. 1556-1571.

Ghannoum, W.M., Moehle, J.P., \& Bozorgnia, Y. (2008). Analytical Collapse Study of Lightly Confined Reinforced Concrete Frames Subjected to Northridge Earthquake Ground Motions. Journal of Earthquake Engineering. Vol 12. pp 1105-1119.

Greifenhagen, C., \& Lestuzzi, P. (2005). Static Cyclic Tests on Lightly Reinforced Concrete Shear Walls. Engineering Structures. Vol. 27. pp. 1703-1712.

Otani, S. (1999). RC Building Damage Statistics and SDF Response with Design Seismic Forces. Earthquake
Spectra. Earthquake Engineering Research Institute. Vol. 15. No. 3. pp 485-501.

Park, R., \& Paulay, T. (1975). Reinforced Concrete Structures. New York: Jhon Wiley \& Sons.

Pawirodikromo, W. (2012). Seismologi Teknik \& Rekayasa Kegempaan. Yogyakarta : Pustaka Pelajar.

Wibowo, A. (2012). Seismic Performance of Insitu and Precast Soft Storey Buildings. Thesis. Tidak dipublikasikan. Melbourne : Swinburne University of Technology.

Wibowo, A., Wilson, J.L., Lam, N.T.K., \& Gad, E.F. (2013). Seismic Performance of Ligthly Reinforced Structural Walls for Design Purpose. Magazine of Concrete Research. Vol. 65. Issue 13. 